\title{
A koronavírusjárvány-helyzet pszichológiai hatásai és azok enyhítése - áttekintő közlemény 441 magyar felnőtt véleményével
}

\author{
Psychological effects of the coronavirus pandemic and their mitigation - \\ review article with opinions from 441 Hungarian adults
}

\begin{abstract}
Szerzők: $\quad$ Szabó Csanád ${ }^{a} \bowtie$, Pukánszky Judit ${ }^{b}$, Kemény Lajos ${ }^{a}$ a: Szegedi Tudományegyetem, Általános Orvostudományi Kar, Bőrgyógyászati és Allergológiai Klinika, Szeged; b: Szegedi Tudományegyetem, Bölcsészettudományi Kar, Pszichológiai Intézet, Szeged
\end{abstract}

Beküldve: 2020. 09. 03.

doi: $\quad$ 10.24365/ef.v61i4.633

\begin{abstract}
Összefoglaló: A koronavírusjárvány-helyzet a globális populáció egy részének pszichés támogatását teheti szükségessé. Tanulmányunk célkitűzése, hogy összefoglaljuk a koronavírusjárvány-helyzet pszichés hatásait, azok enyhítési stratégiáit, és áttekintésünk során saját vizsgálatunkból 441 magyar felnőtt véleményeiből, 48 kiemeléssel szemléltessük a tárgyalt témaköröket. Irodalomkeresésünk a járvány pszichológiai hatásairól 534 cikk találatát eredményezte, melyből 61 kéziratot használtunk fel áttekintésünk elkészítéséhez. Cikkünkben megvizsgáljuk a karanténhoz kapcsolódó stresszforrásokat, viselkedéses és pszichés hatásokat, a médiahatások és médiahasználat témakörét, valamint az alkalmazható gyakorlati tippeket és intervenciós lehetőségeket. A járványhelyzet hatására megnőhet az észlelt stressz szintje, megemelkedhet a szorongásos és depressziós jegyek száma a teljes népességben. Pszichológiai változók hatással lehetnek arra, hogy miként reagál az egyén az újonnan kialakult helyzetre.
\end{abstract}

Kulcsszavak: COVID-19; karantén; mentális egészség; intervenció

Summary: In the coronavirus pandemic, psychological support might be required for a substantial part of the global population. The aim of our study is to summarize the psychological effects of the corona virus pandemic, to describe its mitigation strategies, and to illustrate the topics discussed by exemplifying 48 opinions of 441 Hungarian adults from our own study. In our literature search, we found 534 articles about the psychological effects of the pandemic, of which we reviewed 61 manuscripts. In our article we review the sources of stress associated with quarantine; the behavioural and psychological effects; the media effects and media use; and intervention tips and strategies. As a result of the pandemic, the level of perceived stress, anxiety and depression may increase in the global population. It is also important to add, that psychological variables can affect individual responses.

Keywords: COVID-19; quarantine; mental health; intervention 


\section{BEVEZETÉS}

Háttér

2020 tavaszán a magyar lakosság rendkívüli helyzetbe került: a globális koronavírus-járvány miatti intézkedések megváltoztatták az emberek élethelyzetét.

2020. március 11-én a kormány rendkívüli jogrendet, veszélyhelyzetet hirdetett ki az ország teljes területére a COVID-19 pándémia miatt. ${ }^{1}$

Betiltották a 100 fônél nagyobb beltéri rendezvényeket, és lehetővé tették, hogy házi karanténokat lehessen elrendelni az országban. ${ }^{2}$

A fertőzés elkerülésére a kormány több javaslatot is megfogalmazott, mint például a következőket: a lakosok lehetőleg maradjanak otthon, csak alapos indokkal hagyják el otthonukat; akikkel nem egy háztartásban élnek, azoktól tartsanak legalább 1,5 méteres távolságot; alaposan és gyakran mossanak kezet szappanos vízzel, vagy legalább 60\% alkoholtartalmú kézfertőtlenítővel rendszeresen tisztítsák meg kezeiket; köhögéskor és tüsszentéskor takarják el orrukat és szájukat zsebkendővel, utána dobják ki a zsebkendőt, és mossanak kezet; a megszokott érintkezési, üdvözlési formákat, például a kézfogást,a puszit, a baráti ölelést mellőzzék; az arcmaszk a megbetegedetteknek ajánlott lett, hogy ne terjesszék a vírust egy-egy tüsszentéssel vagy köhögéssel; fokozott figyelem fordítását javasolták immunrendszerük erősítésére, pl. elegendő vitamin fogyasztásával. ${ }^{3}$

Majd 2020 májusának végén elkezdődött a járványhelyzet intézkedéseinek „enyhítése”.

Május 29-én az országban megengedetté vált éttermek, kávézók, cukrászdák, büfék, presszók belső terében való tartózkodás amellett, hogy a vendéglátóhelyeken a 1,5 méteres védőtávolság betartása kötelező maradt, és az ott dolgozók kötelesek voltak a szájat és az orrot eltakaró eszközt viselni. ${ }^{4}$

Lehetővé vált sportrendezvények, kulturális rendezvények, színházi előadások, kiállítások, cirkuszi előadások megtartása is. ${ }^{5}$

Magyarország köztársasági elnöke június 17-én „elrendelte a koronavírus-járvány miatti veszélyhelyzet megszüntetéséről szóló törvény, valamint a veszélyhelyzet megszűnésével összefüggő átmeneti szabályokról és a járványügyi készültségről szóló jogszabály kihirdetését" ${ }^{6}$

\section{Célkitűzés}

Tanulmányunk célkitűzése az, hogy összefoglaljuk a koronavírusjárvány-helyzet pszichés hatásait, és azok enyhítési stratégiáit szakirodalmi keresés alapján, és áttekintésünk során saját vizsgálatunkból 441 magyar felnőtt véleményeiből 48 kiemeléssel szemléltessük a tárgyalt témaköröket.

\section{MÓDSZEREK}

Vizsgálat 2020 tavaszán

A COVID-19 járványhelyzet pszichés hatásait vizsgáltuk 2020 tavaszán a felnőtt magyar lakosság körében egy 65 kérdéses, anonim, on-line kérdőívvel, és kutatásunkban olyan stresszel való megküzdési stratégiákat terveztünk beazonosítani, amelyek segíthettek a járványhelyzet okozta nehézségekkel megbirkózni. ${ }^{7}$ Mérőeszközünk segítségével a következő tényezőket vizsgáltuk: észlelt stressz szintje; szorongásos és depressziós jegyek mértéke; egészségi állapot szintje; „átlagos panaszszám”; gyakori stresszel való megküzdési stratégiák típusa; illetve kettő nyílt kérdés feltevésével a koronavírusjárvány okozta pszichés hatásokat vizsgáltuk (A. „Hogyan hat a koronavírusjárvány-helyzet az Ön hangulatára?”, B. „Mik segíthetnek Önnek abban, hogy megbirkózzon a járványhelyzet okozta nehézségekkel?"). Jelen tanulmányban a felsoroltakból csak a kettő nyílt kérdéssel kapcsolatos adatokat közöljük.

Az Egészségügyi Tudományos Tanács Tudományos és Kutatásetikai Bizottsága (ETT TUKEB) 2020. 04. 29-én megadta a szakmai-etikai engedélyt (ügyiratszám: IV/3484-2/2020/EKU) a vizsgálatunk felvételére.

A projekt tervezett menete a következő volt: első lépésként a kérdőívet internetes weboldalon (www.google.com) készítettük el. Majd a kérdőívet tartalmazó weboldal linkjét a résztvevőknek publikus internetes oldalon (www.facebook.com) három nyilvános csoport internetes felületén keresztül küldtük el. A linkre kattintva minden résztvevő elolvashatta a kérdőív elején lévő tájékoztatót és a beleegyező nyilatkozatot, majd jelezhette részvételi szándékát, és ezután kezdhette el a kérdőív kitöltését. A vizsgálatunkba 18 év feletti magyarországi 
nőket és férfiakat terveztünk bevonni. Megközelítőleg 10-15 percig tartott a kérdőív kitöltése.

\section{Irodalomkeresés}

A PubMed keresőprogrammal a következő paraméterekkel kerestünk közleményeket az elemzéshez: a "covid-19” és a „psychology” kulcsszavak megadásával; 2020. 06. 17-én kerestünk publikációkat; „free full text” típusú kéziratokat kerestünk. A keresés 534 cikk találatát eredményezte. Bizonyos cikkeket nem vettünk bele az elemzésünkbe $(n=333)$ a következő ok miatt: nem vagy csak kismértékben tartalmaztak a koronavírusjárvány-helyzet pszichés hatásairól leírásokat. Összesen 201 kéziratot tanulmányoztunk át részletesen, melyből bizonyos témákat nem használtuk fel tanulmányunk elkészítéséhez, mint például: az online tanítás élményei; kutatói munka a járványhelyzetben; interperszonális erőszak a karanténban; obesitas ellátása a járványhelyzetben; a COVID-19 betegség bőrtünetei; mentális egészségmegőrzés a kollégiumokban; gyermekek és serdülők élményei a járványhelyzetben; idősek ellátása a járványhelyzetben; kiégésprevenció; „morális sérülés” az egészségügyi dolgozóknál; online tudományos konferenciák szervezési módja; szülői nevelés a járványhelyzetben. Így 61 cikk került be elemzésünkbe.

\section{EREDMÉNYEK}

Kutatásunk online kérdőívét az összes résztvevő (441 fő) 2020 májusában töltötte ki, a résztvevők 97\%-a (428 fő) május 7-15. között, 3\%-uk (13 fő) május 19-20. között. 10 fő adatai kizárásra kerültek az analízisből (kilencen nem járultak hozzá a vizsgálatban való részvételhez a kérdőív elején bejelölve azt, egy fő pedig 17 évesen töltötte ki a kérdőívet), így összesen 431 résztvevő adatai maradtak az elemzésben. A résztvevők ( $90 \%(n=387)$ nő) átlag-

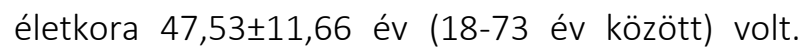
A résztvevők 151 települést írtak be lakóhelyükként, leggyakoribb lakóhelyek Budapest (38\%), Győr (1,9\%), Székesfehérvár (1,9\%), Miskolc (1,6\%), Szeged $(1,6 \%)$ voltak.

A kérdőív kettő nyílt kérdésére adott válaszokból emeltünk összesen 48 mondatot az 1-6. táblázatokba. A résztvevők településeinek nevét gyüjtőfogalmakba rendeztük a települések Tóth
József és munkatársai (8) által publikált, nagyság szerinti csoportosítása alapján annak érdekében, hogy a személyek ne legyenek beazonosíthatóak. A következő kategóriákba soroltuk be a településneveket: törpefalu (500 fő alatt), kisfalu (1000-2000 fő), nagyfalu (2000-5000 fő), óriásfalu (5000-10 000 fő), kisváros (10000-25000 fő), középváros (25 00050000 fó), nagy középváros (50 000-100 000 fő), nagyváros (100 000-250 000 fő), főváros (1-2,5 millió fő). ${ }^{8}$

Az irodalomkeresésünk során elemzett 61 kéziratból hat fejezet mentén készítettük el az áttekintést (zárójelben feltüntetve, hogy a 61 tanulmányból mennyire hivatkozunk az adott témáknál): stresszforrások a karanténban (4); viselkedéses hatások (8); pszichés hatások (43); médiahatások és médiahasználat (5); gyakorlati tippek (4); intervenciós lehetőségek (9). Az elemzett cikkek típusok szerint a következőképpen jellemezhetőek: 25 eredeti kutatásról szóló beszámoló, 20 áttekintő tanulmány, 12 levél a szerkesztőhöz, 4 esetismertetés. Az analizált 25 eredeti kutatásról készült közleményből 22 felnőttekkel készült vizsgálatot mutat be, és 3-ban vettek részt felnőttek mellett 12-18 év közötti fiatalkorúak is. A következő országokban szervezték meg a hivatkozott kutatásokat: Kína (11), USA (3), USA és Kanada (1), Olaszország (2), Spanyolország (2), Németország (1), Pakisztán (1), Szlovákia (1), Ausztrália (1), India (1), globális vizsgálat (1).

\section{Stresszforrások a karanténban}

A járványhelyzet új védekező stratégiák alkalmazását kívánta meg az emberektől: kézmosási szokások megváltozását, a térbeli távolság tartását másoktól, hetekig tartó otthon maradást, a köhögés „eltakarását”, kézfertőtlenítők gyakori alkalmazását, vagy szájmaszk hordását. ${ }^{9}$

Az embereknek bizonytalan helyzetben kellett döntéseket hozniuk, és ezen döntéseiket befolyásolhatták a következő tényezők: az ismeretlentől való félelem, a vírus „láthatatlansága”és különböző társadalmi normák (például az arc érintésének kerülése közösségben). ${ }^{10}$

Járványhelyzetben pletykák és spekulációk terjedhetnek el, az utcák csöndessé válhatnak, gazdasági nehézségek következhetnek be, a háztartási cikkeket felhalmozhatják az emberek. ${ }^{11}$ 
Megjelenhet a megfertőződéstől vagy közeli hozzátartozó megfertőzésétől való félelem. Már a köhögés vagy a COVID-19 tüneteihez hasonló tünetek előfordulása is ijesztőek lehetnek. A karanténhelyzet unalmat, a napi rutin elvesztését, frusztrációt okozhat. Ezt növelhetik olyan tényezők, ha valaki nem tudja ellátni a napi teendőit, vagy nem képes személyesen megvásárolni alapvető élelmiszereket. Megbélyegezhetik, hibáztathatják a körülöttük élők azokat, akiket fertőzöttség vagy akár csak annak gyanúja miatt házi karanténba helyeztek. ${ }^{12}$

1. táblázat: „Stresszforrások a karanténban” témában a „Hogyan hat a koronavírusjárvány-helyzet az Ön hangulatára?” kérdésre adott válaszok közül kiemelések magyar felnőttektől (n=431)

\begin{tabular}{|c|c|c|c|}
\hline Idézet & Nem & Életkor & Lakóhely \\
\hline $\begin{array}{l}\text { „Részben jó, mert home office-ban itthon lehetek. Részben rossz, mert a férjem } \\
\text { tiszta dilis, hogy a fiam hazahozza a vírust az érettségiről... és emiatt utálkozását } \\
\text { fejezi ki, ami számomra elfogadhatatlan. Neki nem a fia..... szóval kezd elegem } \\
\text { lenni... de ennek nyilván nem feltétlen a vírus az oka...” }\end{array}$ & Nő & 56 & középváros \\
\hline $\begin{array}{l}\text { „A vírus maga sehogy, a mellé járó kellemetlenségek (így lassan két hónap után) } \\
\text { eléggé bosszantanak. De mivel } 3 \text { gyerekkel töltöm a napjaim, így odafigyelek, hogy } \\
\text { ne legyenek komolyabb problémák.” }\end{array}$ & Nő & 33 & kisfalu \\
\hline „Nagyon rosszul! Hiányoznak a gyerekek, meg az unokám!” & Nő & 66 & nagyfalu \\
\hline $\begin{array}{l}\text { „Először nagyon stresszeltem, a testvérem lélegeztetőgépen is volt, de most } \\
\text { hogy túlvagyunk a nehezén, jólesik az otthonlét.” }\end{array}$ & Nő & 24 & főváros \\
\hline $\begin{array}{l}\text { „Türelmetlen, hogy nem utazhatok unokámhoz, s várandós lányomhoz! Hiányzik a } \\
\text { személyes kapcsolat.” }\end{array}$ & Nő & 65 & főváros \\
\hline „Az unokák távolléte nagyon megvisel!” & Nő & 62 & nagyváros \\
\hline $\begin{array}{l}\text { „Változóan, attól függ, hogy alakulnak éppen a személyes dolgaim. Mivel sok } \\
\text { munkát, remek lehetőséget, előrelépést buktam el miatta, most éppen eléggé } \\
\text { elegem van a helyzetből." }\end{array}$ & Nő & 37 & főváros \\
\hline „Lehangol a tudat, hogy ki tudja, mikor lesz vége, és áll vissza a normális élet.” & Nő & 45 & föváros \\
\hline $\begin{array}{l}\text { „Stresszelek, hogy végezzünk a gyerek oktatásával, mire ebédet kell főznöm, aztán } \\
\text { dolgoznom kell.” }\end{array}$ & Nő & 30 & főváros \\
\hline $\begin{array}{l}\text { „Rettegek, hogy a szeretteim nehogy elkapják a vírust, mert több veszélyeztetett } \\
\text { is van köztük." }\end{array}$ & Nő & 39 & főváros \\
\hline $\begin{array}{l}\text { „Szerencsére a munkám rengeteg kihívást tartogat, ezért az leköti a figyelmem, } \\
\text { valamint nincs anyagi bizonytalanság az életemben, illetve a párkapcsolatom is jól } \\
\text { múködik, egyáltalán nem konfliktusforrás. Mondhatni változatlan időszakot élünk, } \\
\text { a hangulat többnyire jó és pozitív.” }\end{array}$ & Nó & 32 & főváros \\
\hline „Eleinte félelmetes volt, kiszolgáltatottságot jelentett. Háborús érzetekkel.” & Nő & 64 & főváros \\
\hline $\begin{array}{l}\text { „Amikor megtudtam, hogy a közvetlen szomszédom beteg, dühös lettem, mert } \\
\text { tudtam, hogy csakis ő volt felelőtlen." }\end{array}$ & Nő & 49 & nagyváros \\
\hline „Kellemes volt, életem leghosszabb idejű pihenése, szórakozása itthon, egyedül.” & Nő & 65 & kisváros \\
\hline
\end{tabular}

Forrás: saját szerkesztés

\section{Viselkedéses hatások}

A karantén sokféle új viselkedésformát követelt meg a lakosságtól: gyakori és helyes kézmosást, személyek közötti távolságtartást, otthoni izolációt, köhögés és tüsszentés etikettjét, fertőtlenítőszerek használatát és maszkviselést. ${ }^{9}$ A maszkviselés munkahelyi tapasztalataival kapcsolatban Corruble kiemeli, hogy problémát okozhat az arckifejezések megkülönböztetése, így egymás sikeres megértése további erőfeszítéseket igényelhet. ${ }^{13}$
A járványhelyzet miatt kialakult új elvárásokhoz és szokásokhoz igazodva sokan a családtól, barátoktól izolálva érezték magukat. A munkahelyek elvesztése, megszűnése miatt gyakoriakká váltak az anyagi problémák. A stresszre adott válaszként pánikszerü vásárlások és felhalmozás jelent meg, így a boltokban készlethiány alakult ki tejből, tojásból, WC papírból, fertőtlenítőszerekből, egyes gyógyszerekből. ${ }^{14} \mathrm{~A}$ rögzült társas normákon, melyek a viselkedést befolyásolják, ugyanakkor nagyon nehéz 
változtatni, például közös ebéd a barátokkal, térbeli közelség a kollégákkal, nagyszülőkkel való személyes törődés. A szükséges változásokkal kapcsolatban pedig gyakran ellenállás figyelhető meg. ${ }^{10}$

Német vizsgálati személyek viselkedéses válaszai március 2020. március 15-20. között a következők voltak: a megkérdezettek ( $n=1615$ ) közül 94,7\% többször mosott kezet, mint a járvány előtt, 85,2\% interneten szerzett ismereteket a vírussal kapcsolatban, 52,1\% több fertőtlenítőszert használt, 23\% több élelmiszert vásárolt, 15,6\% felhalmozott élelmiszert otthon, $9 \%$ több higiéniai terméket vásárolt, 2,4\% ment orvoshoz. A szociális távolságtartással kapcsolatban 91,9\% kerülte a tömeget, 94,1\% kerülte a nagyobb eseményeket, $80,1 \%$ kerülte az utazást Németországon belül és 89,5\% kerülte az utazást külföldre. ${ }^{15}$

Pakisztánban 2020 márciusában a 400 résztvevő válaszai alapján a következő viselkedéssel kapcsolatos hatásokra világítottak rá: a megkérdezettek közül 14,8\% inkább beteget jelentett a vírusfertőzéssel kapcsolatos félelmek miatt, hogy ne kelljen dolgozni vagy képzésre mennie, 24,8\% pedig a felmondását, illetve a tanulmányai bejezését fontolgatta.
A fertőzés elkerülése érdekében a válaszadók háromnegyede változtatott a viselkedésén: 86,5\% csökkentette a közeli társas kontaktusokat, 74,5\% elkerülte vagy csökkentette az egészségügyi intézmények látogatását, 84,5\% lemondta a korábban tervezett programokat (például családi találkozók, utazások), $87 \%$ gyakrabban mosott kezet. 35\% elkezdte kerülni a hírek fogyasztását, mivel az fokozta a szorongást. 54,5\% azért vásárolt élelmiszert, mert félt, hogy az el fog fogyni. ${ }^{16}$

A számítógépes játékhasználat szerepet játszhat a stresszel való megküzdésben, indiai egyetemisták (college) körében ( $n=128)$ vizsgálták jellemzőit a COVID-19 járványhelyzet alatt. A megkérdezettek fele $(50,8 \%)$ jelezte a számítógépes játékhasználat növekedését, míg 14,6\% csökkenésről számolt be. ${ }^{17}$

A járványra jellemző életmódbeli szokások vizsgálatát is magában foglalta egy 2020. január-február időszakában végzett kínai, kérdőíves vizsgálat. $A z$ eredmények szerint a megkérdezett felnőttek (n=263) 62\%-aa vizsgált időszakban több időt töltött pihenéssel, $64,2 \%$ többet relaxált, 59,7\% több időt szánt testmozgásra. ${ }^{18}$

2. táblázat: „Viselkedéses hatások” témában a „Hogyan hat a koronavírusjárvány-helyzet az Ön hangulatára?”

(A) és a „Mik segíthetnek Önnek abban, hogy megbirkózzon a járványhelyzet okozta nehézségekkel?”

(B) kérdésre adott válaszok közül kiemelések magyar felnőttektől $(n=431)$

\begin{tabular}{|c|c|c|c|}
\hline Idézet & Nem & Életkor & Lakóhely \\
\hline (B) „Ha aludhatnék, míg véget nem ér....” & Nő & 56 & középváros \\
\hline (B) „Sokkal több alkohol tartalmú italt fogyasztok.” & Férfi & 34 & óriásfalu \\
\hline $\begin{array}{l}\text { (B) „Ha jó idő van, kiülök az erkélyre egy kicsit. Esténként megiszok egy pohár alko- } \\
\text { holt.” }\end{array}$ & Nő & 41 & főváros \\
\hline $\begin{array}{l}\text { (A) „Egy vírusfajta, olyasmi, mint az influenza. Valaki könnyen átvészeli, más nehe- } \\
\text { zebben. Nem foglalkozok vele. Egészségesnek tartom magam, vitaminokat előtte is } \\
\text { szedtem és sportolok. Mozgásban vagyok. Nagy a hangja....szerintem!” }\end{array}$ & Nő & 58 & nagy középváros \\
\hline $\begin{array}{l}\text { (B) „Ha végre feloldják a korlátozásokat és lesz megint óvoda, találok munkát, me- } \\
\text { hetünk a gyerekekkel strandra, a párommal kettesben beülhetek egy kávéra vala- } \\
\text { hova. Már } 4 \text { éve vagyok itthon két kislányommal, és pont januárban kezdtem mun- } \\
\text { kát keresni, mert ha lejár a gyedem, nem lesz semmi pénzem, és már ettől gyomor- } \\
\text { idegem van.” }\end{array}$ & Nő & 37 & kisváros \\
\hline $\begin{array}{l}\text { (A) „Március közepe óta itthonról, távmunkában dolgozom. Még soha nem volt } \\
\text { ilyen nyugodt, kiszámítható, tervezhető és eredményes a napi munkám. Élvezem.” }\end{array}$ & Nő & 60 & óriásfalu \\
\hline $\begin{array}{l}\text { (A) „Teljesen ki vagyok most már idegileg. Egyszerűen sehova nem lehet menni, } \\
\text { semmit nem lehet csinálni, mert itt van a vírus. Egyszerűen elegem van az egész- } \\
\text { ből.” }\end{array}$ & Nő & 27 & középváros \\
\hline $\begin{array}{l}\text { (A) „Változó. Az elején ijesztő volt, de tettem a dolgom, igyekeztem mindenkit felvi- } \\
\text { dítani magam körül. Mostanra kezd sok lenni az itthonlét, ezt igyekszem relaxálás- } \\
\text { sal, meditációval kezelni. Mindent összevetve másoknál jobban türöm a helyzetet.” }\end{array}$ & Nő & 41 & törpefalu \\
\hline
\end{tabular}




\begin{tabular}{|c|c|c|c|}
\hline $\begin{array}{l}\text { (A) „Változó. Igyekszem minden előírást betartani, de az zavar, ha pl. utcán a velem } \\
\text { szembe jövő nem tartja be. Amúgy reménykedem, hogy előbb-utóbb minden } \\
\text { rendbe jön, még ha nem is lesz minden "olyan", mint régen volt. De ez talán nem is } \\
\text { baj." }\end{array}$ & Nő & 60 & fóváros \\
\hline $\begin{array}{l}\text { (A) „Óvatosabb vagyok, de nem félek. Betartom a szabályokat, igyekszem példát } \\
\text { mutatni a magatartásommal. Amit tudok, megteszek, hogy elkerüljem a megfertő- } \\
\text { ződést, de ha jönnie kell, akkor jöjjön. Állok elébe.” }\end{array}$ & Nö & 46 & $\begin{array}{l}\text { ismeretlen tele- } \\
\text { pülés }\end{array}$ \\
\hline $\begin{array}{l}\text { (A) „Próbálok jobban odafigyelni (kezdődő asztma, pajzsmirigyprobléma, túlsúly, } \\
\text { magasvérnyomás-betegség), és elfogadom az adott helyzetet.” }\end{array}$ & Nő & 56 & fóváros \\
\hline
\end{tabular}

Forrás: saját szerkesztés

\section{Pszichés hatások}

A koronavírusjárvány-helyzet hatására:

- megnőhet az észlelt stressz szintje, 11,19,20,21,22,23,

$24,25,26,27,28,29,30,31,32,33,34,35,36,37,38,39,40,41,42,43$

- megemelkedhet a szorongásos jegyek száma,

$11,16,19,20,21,22,23,24,28,29,30,31,32,33,34,36,37,38,39,40,41,43,44,45,46$,

$47,48,49,50$
- megnőhet a depressziós jegyek száma. ${ }^{11,19,20,21,22,}$ $23,24,28,29,30,31,32,33,34,36,37,38,41,43,45,46,47,49$

Ezek mellett a tényezők mellett számos más lelki hatással járhat a járványhelyzet, ezeket részletezzük ebben a szekcióban.

3. táblázat: „Pszichés hatások” témában a „Hogyan hat a koronavírusjárvány-helyzet az Ön hangulatára?” kérdésre adott válaszok közül kiemelések magyar felnőttektől $(n=431)$

\begin{tabular}{|c|c|c|c|}
\hline Idézet & Nem & Életkor & Lakóhely \\
\hline $\begin{array}{l}\text { „A járványhelyzet kihirdetése után előjöttek a szorongásos tünetek. Még jó, hogy } \\
\text { volt itthon Frontin (3-4 napig szedtem este a legenyhébbet) és Scippa (ebből reggel } \\
\text { egyet szedek, hirtelen nem is tudom, hogy a legenyhébbet-e vagy a következőt).” }\end{array}$ & Nő & 43 & főváros \\
\hline $\begin{array}{l}\text { „Március 12. óta (2020.05.07-i felvétel) háromszor voltam kinn az utcán, félek ki- } \\
\text { menni, még amikor a szemetet viszem ki vagy a postaládához megyek, az is féle- } \\
\text { lemmel tölt el.” }\end{array}$ & Nő & 43 & fóváros \\
\hline $\begin{array}{l}\text { „Rosszul. Depressziót, kilátástalanságot okoz. Érzem, hogy itt valami "más" is van a } \\
\text { háttérben, ami a jövőben negatívan befolyásolja az életünket.” }\end{array}$ & Nő & 43 & óriásfalu \\
\hline $\begin{array}{l}\text { „A kényszerű bezártság visszahozta a korábbi években - GYES alatt - tapasztalt izo- } \\
\text { láltság rémes időszakát. Az első három hétben szinte katatón módon próbáltam } \\
\text { túlélni, de aztán elővettem kis adagban az antidepresszánst. Néha inkább bejárok } \\
\text { az irodába másokkal találkozni, még ha kockázatos is." }\end{array}$ & Nő & 50 & főváros \\
\hline „Szeretem ezt a lelassulást. Nem vagyok tőle depressziós.” & Nő & 50 & nagyfalu \\
\hline $\begin{array}{l}\text { „Többet szorongok az egzisztenciális helyzetemen, könnyebben sírva fakadok (örö- } \\
\text { mömben-bánatomban egyaránt), felértékelődött bennem a szeretet, türelmesebb } \\
\text { vagyok, elengedtem a jövőtől való félelmet, és a jelenre koncentrálok. Kicsit önzőb- } \\
\text { bek lettek a gondolataim.” }\end{array}$ & Nő & 33 & fóváros \\
\hline $\begin{array}{l}\text { „Örülünk, hogy együtt a család non-stop! Szeretünk itthon lenni! Így maradhatna!!! } \\
\text { Hangulatom végtelenül nyugodt!” }\end{array}$ & Nő & 42 & nagyváros \\
\hline „Egyelőre élvezem az itthonlétet, nem hiányoznak a kollégák és a munka.” & Nő & 50 & főváros \\
\hline $\begin{array}{l}\text { „Home office kényelmét élvezem, de gyakran túlórába esem. Néha hiányoznak a } \\
\text { kollégáim. Családi ház kertjében biztonságban érzem magam, de hiányzik az utazás, } \\
\text { hiányoznak a nagy, családi, baráti összejövetelek. Dühít sok ember nemtörődöm- } \\
\text { sége.” }\end{array}$ & Nő & 37 & kisváros \\
\hline $\begin{array}{l}\text { "Sokat pihenek, bepótoltam az elmaradt dolgaimat... pozitívan hat rám inkább, } \\
\text { nem hisztizek, nem aggódom túl magam." }\end{array}$ & Nő & 49 & óriásfalu \\
\hline $\begin{array}{l}\text { „Nagyon ideges lettem. Tüneteim: pánikrohamok, hasmenés, hányás hetekig! Fáj- } \\
\text { dalmas allergiás bőrtünetek, (ekcéma?) általános remegés, zsibbadás, izomláz. Ext- } \\
\text { rém magas vérnyomás, sírás, napi max. } 2 \text { óra alvás. Koncentráció hiánya. Elveszítet- } \\
\text { tem a munkám." }\end{array}$ & Nő & 42 & középváros \\
\hline $\begin{array}{l}\text { „Engem nem befolyásolt rossz irányban, számtalan pozitív hozadéka lett az életem- } \\
\text { ben. Természetesen maga a járvány ténye és az, hogy emberek haltak meg és }\end{array}$ & Nő & 56 & főváros \\
\hline
\end{tabular}


betegedtek meg az elszomorít, ettől elszakadva viszont ugyanaz az életvidám ember vagyok, amilyen járvány előtt is voltam."

„Kimerítő ez a bezártság, a várakozás a végére, az elszigeteltség elmagányosít, már nem elég a virtuális kapcsolódás, már a 10. naptól kezdve elkezdtem érezni a türelmetlenséget, és egyre fokozódott bennem a lázadás, hogy kitörjek, akármi is lesz, nekem is meglepőek voltak ezek a belső reakciók. „Természetesen visszafojtottam, de attól az még ott feszül bennem azóta is. Még jó, hogy már képes vagyok moderálni magam, még ha nehezemre is esik. Átalakultak az értékrendjeim!"

Forrás: saját szerkesztés

\section{Temperamentum}

Olasz vizsgálatban a temperamentum és a kötődési stílus pszichés hatásait vizsgálták 500 személynél a járványhelyzet elején. Közepes mértékű, illetve jelentős pszichés distressz kockázati faktora volt a ciklotim, a depresszív és a szorongó temperamentum. A biztonságos és az elkerülő kötődés védőfaktort jelentettek a járványhelyzet okozta pszichés megterheléssel szemben. Elkerülő kötődésnél a társas izoláció kevésbé járt distresszélménnyel, így a járványintézkedések során bevezetett társas korlátozások sem okoztak akkora distresszt, mint a szorongó kötődés esetén. ${ }^{51}$

\section{Pánikbetegség}

A járványhelyzet pánikzavart okozhat olyan személyeknél is, akiknek nem volt pszichiátriai kórelőzménye. Bhatia és munkatársai tanulmányukban bemutattak egy 28 éves indiai férfit, aki epizodikus légszomjjal, mellkasi fájdalommal, valamint a koronavírus-fertőzéssel kapcsolatos félelmek miatt kereste fel a kórházat. ${ }^{52}$ Az organikus okok kizárását követően pánikbetegséget diagnosztizáltak. Nem találkozott fertőzött személlyel, nem utazott magasabb kockázattal járó területekre, nem tapasztalt COVID-19-re jellemző tüneteket. A félelmek globálisan jelentek meg a koronavírussal kapcsolatban, illetve saját és családtagjainak megfertőződésére vonatkozóan. Korábban a férfit nem diagnosztizálták pszichiátriai betegséggel, krónikus betegségekkel, függőségi zavarokkal, és nem állt a múltban kórházi kezelés alatt. ${ }^{52}$

\section{Pszichózis}

A járványhelyzet olyan embereknél is okozhat pszichotikus tüneteket, akiket diagnosztizáltak pszichózissal, de olyan személyeknél is megjelenhetnek hallucinációk, téveszmék, akiknél nem diagnosztizáltak pszichózist. ${ }^{53,54}$

Fischer és munkatársai a következő pszichotikus tüneteket publikálták egy 43 éves német férfi kapcsán: azt vélte hallani, hogy a szomszéd férfi és nő őt hibáztatják azért, hogy mentőtisztként nem vigyázott megfelelően a szüleire, akik meghalhattak volna a COVID-19 betegségtől. ${ }^{53} \mathrm{~A}$ szomszédból hallott hangok azt is mondták neki, hogy az összes szomszédja meghalhatott volna az ő hanyagsága miatt. A férfi felismerte, hogy a hangok hallucinációkhoz kapcsolódhatnak, de ennek ellenére az egyik éjszaka közepén elment szülei házához, hogy megnézze, élnek-e, de úgy döntött, hogy nem megy be a házukba. Azt gondolta emellett, hogy megfigyelik őt kamerákkal, és hogy immunis lett a koronavírusfertőzésre, mert korábban megfertőzte őt egy kínai üzenet, amit egy WhatsApp csoportban kapott. A páciens sikeres kezelése kapcsán a járvánnyal kapcsolatos auditoros hallucinációi először elhalványultak, majd megszúntek, illetve szorongása és feszültsége csökkent. ${ }^{53}$

Hajdúk és munkatársai 235 szlovák egyetemista 2020 áprilisi vizsgálatával azt találták, hogy a pozitív pszichotikus tünetek száma kapcsolatban állt a depresszió szintjének megemelkedésével. ${ }^{54}$

\section{Alvásminőség}

A járványhelyzet mint stresszforrás megakadályozhatja a megfelelő minőségű alvást. Az otthoni munkavégzés felboríthatja a megszokott napi rutint és munkával kapcsolatos határidőket, melynek következtében az otthonnal, a pihenéssel és az alvással kapcsolatban negatív asszociációk jelenhetnek meg. Megnehezíthetik az alvást a következők: kisebb fénymennyiségnek való kitettség, kevesebb edzés és a gyakoribb étkezés. ${ }^{23}$

Egy 2020 februári kínai vizsgálatban Xue, Lin és Zhang megvizsgálták, hogy a résztvevők hány 
százalékának voltak legalább egy napon alvási problémái a felmérést megelőző héten, és a következőket találták: az egészségügyi elkülönítésben lévők 76,7\%-a, az önkéntes karanténban lévők 51\%-a és 42,3\%-a azoknak, akik nem számoltak be arról, hogy izolációban élnek. ${ }^{55}$

Zhao és munkatársai tanulmánya szerint kínai embereknél az önbecsülés magas szintje jó hatással volt az alvásminőségre. ${ }^{42}$

\section{COVID Stress Scales}

Taylor és munkatársai kifejlesztették a "COVID Stress Scales" kérdőívet, egy 36 kérdéses skálát a koronavírus járványhelyzettel kapcsolatos stresszreakciók és szorongáshoz kapcsolódó jegyek mérésére. ${ }^{56} 3479$ kanadai és 3375 egyesült államokbeli személlyel (mindkettő országból reprezentatív mintát gyűjtve) vizsgálták meg kérdőívük érvényességét. Öt faktorra bontották a skála által mért jellemzőket: 1 . veszélyérzet és fertőzéses félelmek, 2. félelmek a gazdasági következményeket illetően, 3. xenofóbia, 4. kompulzív ellenőrzés és megnyugvás keresése, 5. traumatikus stressztünetek a járvánnyal kapcsolatban. Példák az öt faktort vizsgáló itemekre: 1. „Aggaszt, hogy a levelemet megfertőzte-e a postás.” 2. „Aggaszt, hogy az üzletek kifogynak élelmiszerekből”. 3. „Ha találkoznék egy külföldi országból származó emberrel, aggasztana, hogy fertőzött-e a vírussal.” 4. „Problémám volt a koncentrálással amiatt, hogy sokat gondoltam a vírusra." 5. „Youtube videókat néztem a COVID-19 betegséggel kapcsolatosan."A skálának mind a 36 itemére a választ 0-4-ig tartó ötfokú skálán (0=egyáltalán nem, 4=extrém mértékben; és gyakoriságra kérdezésnél $0=$ soha, 4=majdnem mindig) kellett bejelölnie a résztvevőknek, ahol az elmúlt egy hétre vonatkoztak a kérdések. A kérdőív a szerzők vizsgálata alapján érvényesnek és megbízhatónak bizonyult. Az eredményeik alapján „COVID-19 Stressz Szindrómáról” beszélhetünk a járvány pszichológiai hatásai tekintetében. A szerzők szerint a skála alkalmas a következő tényezők mérésére: a koronavírusjárvány-helyzettel kapcsolatos distressz jobb megértésére; azon személyek beazonosítására, akiknek kiemelten szüksége lehet mentálhigiénés támogatásra; annak megvizsgálására, hogy egy adott csoportból kik azok a személyek, akik a legvalószínúbben alkalmaznak védekezési stratégiákat a koronavírus-fertőzés ellen. ${ }^{56}$

\section{Túlzott foglalkozás a vírussal}

Lee 2020 márciusában a járványhelyzettel kapcsolatos túlzott foglalkozást vizsgálta 1173 Egyesült Államokban élő felnőtt megkérdezésével. ${ }^{57}$ Eredményként azt találta "túl sok” foglalkozásnak a járvánnyal, ha egy résztvevő az utóbbi kettő hét alatt legalább három-hét napon tapasztalta azt, hogy a koronavírussal kapcsolatban álmodott; repetitíven gondolkozott a koronavírusról; felkavaró gondolatai voltak arról, hogy elkaphatta a vírust; felkavaró gondolatai voltak arról, hogy bizonyos emberek koronavírusos fertőzöttek, akikkel találkozott. Az ilyen jellegú túlzott foglalkozás a járvánnyal gyakori klinikai szintű szorongás esetén, és kapcsolatban állt például alkohol, drogalapú megküzdési stratégia alkalmazásával, és szuicid gondolatok megjelenésével is. ${ }^{57}$

\section{Egészségszorongás és szomatikus tünetzavar}

A magas és alacsony egészségszorongás kedvezőtlen hatással bírhat az egyénre és a közösségre vonatkozóan. Magas egészségszorongás maladaptív viselkedéshez vezethet (túlzott kézmosás, társak kerülése, pánikvásárlás), az egyén tévesen értelmezi testi jelzéseit és tüneteit, mely fokozza a szorongást. Alacsony egészségszorongás esetén viszont az egyén kevésbé tarja be a vírusterjedés megelőzésére vonatkozó ajánlásokat. ${ }^{48}$

A szomatikus tünetzavarnál jellemző, hogy a személy diszfunkcionális mértékben figyel testi tünetekre, és emiatt szükségtelenül használ egészségügyi szolgáltatásokat. Colizzi és munkatársai tanulmányukban leírták, hogy egy 16 éves olasz fiú COVID-19 betegségtől való félelme szomatikus tünetzavart váltott ki nála. ${ }^{58} \mathrm{~A}$ páciens a kórházba való bejelentkezésének napján tudomást szerzett negatív koronavírustesztjéről, és ezt követően is agitáltság és agresszió jeleit mutatta édesanyja irányába, amely viselkedés édesanyja szerint szokatlan volt a fiánál. A páciens számára pszichiátriai kezelést írtak elö, amely klinikailag stabillá tette állapotát, és hatására szubjektív jóllétről számolt be a páciens. A szerzők felhívták a figyelmet arra, hogy 
a szomatikus tünetzavar monitorozása a járvány idején fontos lehet. ${ }^{58}$

\section{Médiahatások és médiahasználat}

A járványhelyzettel kapcsolatos hírek hatással lehetnek a lakosság gondolkodásmódjára, és a karantén megváltoztathatja a médiafogyasztási és szociális médiahasználati szokásokat.

McFadden és munkatársai megkérdeztek 718 egyesült államokbeli felnőtt személyt, akik az eredmények alapján a legmegbízhatóbb információforrásnak az egészségügyi szakembereket tartották, ezt követte a televízió, a nyomtatott sajtó, a weboldalak, a barátok/család, legkevésbé pedig a közösségi médiafelületeken közölt információban bíztak. ${ }^{9}$

A interneten található téves információkkal szemben az egészségügyi szakemberek modellszemélyként való megjelenése segítséget nyújthat a rögzült társas normák, illetve a viselkedés megváltoztatásában. Ez történhet szlogenek, képek, személyes példák bemutatásán keresztül. ${ }^{10}$

Kínában a COVID-19 bejelentése (2020. január 20.) előtti és az azt követő hét mikroblogbejegyzéseinek elemzését végezték el a Weibo nevű platform 17865 aktív felhasználójának bevonásával. (A Weibo egy olyan felület, ahol a felhasználók információkat oszthatnak meg magukról, és reagálhatnak egymásra.) A COVID-19 bejelentését követően a negatív érzelmekhez kapcsolódó szavak (szorongás, depresszió, felháborodás) növekedése, a család és egészség körüli aggodalom fokozódása, valamint a szabadidő és barátok miatti aggodalom csökkenése jelent meg a vizsgált szövegekben. Azonban a pozitív szavak gyakorisága (például áldás, hit) is szignifikánsan növekedett, mely a csoportkohézió fokozódásával mutathat összefüggést, a csoportot érintő fenyegetés következményeként. ${ }^{59}$
A COVID-19 járványhoz kapcsolódó négy érzelem (félelem, düh, szomorúság, öröm) gyakoriságának vizsgálata céljából több mint húszmillió, 2020. január 28 - 2020. április 9. között megjelent angol nyelvű Twitter-posztot elemeztek, 170 ország több mint 7 millió felhasználóját bevonva. Az eredmények a negatív érzelmek dominanciájára mutattak rá a vizsgált időszakban: a napi tweetek elemzése alapján a vírus megjelenésekor a félelem kifejezésének gyakorisága megnövekedett (például félelem a COVID-19 tesztek hiánya miatt), melyet napokon belül a harag kifejezésének növekedése váltott fel (például az otthoni izolációval kapcsolatban), majd a harag kifejezése a világjárvány bejelentését követő naptól kezdve (március 12-től) csökkent. Emellett a szomorúság (például barátok, családtagok elvesztése miatt), és az öröm (például hála és egészség kifejezésével) szintén megjelent a vizsgált bejegyzések között. ${ }^{60}$

A médiahasználat és pszichés következmények kapcsolatát vizsgálták kérdőívvel kínai felnőtt személyek körében a járvány kezdetén (2020. január végén). Az új médiafelületek (weboldalak, online videók, közösségi oldalak) látogatása negatívabb pszichés következményekkel mutatott összefüggést (negatív hangulat, depresszió, szorongás, stressz), mint a tradicionális média (TV, rádió, újság) használata, mely esetében nem találtak a pszichés hatásokkal szignifikáns kapcsolatot. A nagyobb bevonódás (pl. a járvánnyal kapcsolatos tartalmak gyakori posztolása, járványhelyzettel kapcsolatos hírekre való keresés) szintén negatív érzelmi hatást gyakorolt, valamint a hosszabb médiahasználattal töltött idő magasabb stressz- és szorongásszinttel járt együtt. Ezzel szemben a betegséggel és megelőzéssel kapcsolatos információkkal való találkozás kevesebb depresszív tünettel járt együtt, mely fokozhatja az egyén preventív viselkedését és aktív megküzdését. ${ }^{61}$ 
4. táblázat: "Médiahatások és médiahasználat” témában a „Hogyan hat a koronavírusjárvány-helyzet az Ön hangulatára?” (A) és a „Mik segíthetnek Önnek abban, hogy megbirkózzon a járványhelyzet okozta nehézségekkel?”

(B) kérdésre adott válaszok közül kiemelések magyarfelnőttektől $(n=431)$

\begin{tabular}{|c|c|c|c|}
\hline Idézet & Nem & Életkor & Lakóhely \\
\hline (B) „Jó hogy van wifi, és online élelmiszer-házhozszállítás.” & Nő & 71 & főváros \\
\hline (B) „Nem nézem a híreket, pozitívan gondolok a kimenetelre.” & Nő & 63 & főváros \\
\hline $\begin{array}{l}\text { (A) "Már nagyon unalmas, nehéz eldönteni, hogy a sok információ közül mi lehet } \\
\text { igaz, és mi nem." }\end{array}$ & Nő & 44 & középváros \\
\hline
\end{tabular}

Forrás: saját szerkesztés

\section{Gyakorlati tippek}

A karanténhelyzet nehézségeivel való megküzdést bizonyos esetekben gyakorlati tippek is segíthetik.

Kínai ápolóknak, akik intenzív osztályos ellátásban COVID-19 fertőzött páciensekkel dolgoztak, Shen és munkatársai többek között a következő módszereket javasolták, illetve alkalmaztak lelki támogatásukhoz:

- munkabeosztásuknál figyeltek arra, hogy tudjanak megfelelően pihenni,

- pszichológust alkalmaztak arra, hogy az egészségügyi csoportokat támogassa,

- ösztönözték őket arra, hogy megosszák egymással a sikeres kezelések tapasztalatait,

- serkentették őket érzelmeik megosztására feszültségük és szorongásuk csökkentése érdekében,

- részt vehettek relaxációs gyakorlatban,

- bíztatták őket arra, hogy kommunikáljanak hasonló helyzetben lévő kollégákkal,

- ösztönözték őket online felületen kapcsolattartásra családtagokkal,

- létrehoztak egy szakértői team-et, amely tagjai mentálhigiénés tréninget, iránymutatást, egyéni pszichoterápiás segítséget vagy pszichiátriai kezelést adhattak ápolóknak. ${ }^{62}$

Fiorillo és Gorwood szerint érdemes figyelni a következő tényezőkre:

- a napnak csak egy előre meghatározott részében foglalkozni a járványhelyzettel kapcsolatos online információkkal, ezzel korlátozva az egyént érő stresszforrások mennyiségét,

- tartani a kapcsolatot a szeretett személyekkel, még ha online felületek segítségével is, ezzel csökkentve az esetleges magányosságérzetet vagy bizonytalanságot,

- ha valakinek beszúkült a kapcsolati hálója, szükség esetén támogatást kérni lelkisegély-vonalon keresztül,

- rendszerességre törekedni az alvási idő és az étkezési szokások tekintetében,

- intellektuális, fizikális és társas programok szervezése az addiktív viselkedésformák megelőzésére (amelyek gyakorivá válására kockázatot jelenthet a karanténhelyzet),

- szem előtt tartani azt, hogy az otthonmaradás milyen előnyökkel járhat: például saját magunk és a hozzánk közel állók védelmével,

- ha úgy érzi az illető, hogy „elárasztja” őt a stressz, akkor megfelelő pszichés támogatást igénybe venni. ${ }^{37}$

Rhedelmeier és Shafir a rendszeres testmozgás fontosságát hangsúlyozzák járványi idején. ${ }^{10}$

A szerzők szerint azok, akiknek krónikus betegségük van, érdemes ügyelniük arra, hogy ne szúküljön be a figyelmük a vírus elleni védekezésre, ne hanyagolják el a törődést az alapbetegségükkel a járványhelyzetben. ${ }^{10}$

Mazza és munkatársai a mindfulness-alapú meditációt is ajánlják a járványhelyzet okozta feszültségekkel megküzdéshez. ${ }^{41}$ 
5. táblázat: „Gyakorlati tippek” témában a „Mik segíthetnek Önnek abban, hogy megbirkózzon a járványhelyzet okozta nehézségekkel?” kérdésre adott válaszok közül kiemelések magyar felnőttektől (n=431)

\begin{tabular}{|c|c|c|c|}
\hline Idézet & Nem & Életkor & Lakóhely \\
\hline $\begin{array}{l}\text { „Az egzisztenciális biztonság, hogy itthon van a családom, és jól érezzük magunkat } \\
\text { egymással, hogy van elegendő helyünk és kertünk, hogy online sok jó emberrel tu- } \\
\text { dom tartani a kapcsolatot, hogy találtunk új szakmai válaszokat és fejlődünk." }\end{array}$ & Nő & 49 & nagyfalu \\
\hline $\begin{array}{l}\text { „A párkapcsolatom, a családommal töltött idő, az együttes élmények, a testmozgás } \\
\text { - elsősorban a férjemmel közös napi séta, gyaloglás.” }\end{array}$ & Nő & 44 & nagy középváros \\
\hline $\begin{array}{l}\text { „Barátok, ismerősök telefonjai, levelei,a párom szeretete,a fiam figyelmessége, fil- } \\
\text { mek, könyvek,online testedzés,online kiállítások,virágok gondozása,társasjáték, pi- } \\
\text { henés,restanciák felszámolása, valami újdonságba belefogni(kenyérsütés, olasz } \\
\text { nyelv tanulása).” }\end{array}$ & Nő & 63 & fóváros \\
\hline $\begin{array}{l}\text { "Párom jelenléte és támogatása, barátaim, rokonaim figyelmessége, segítségük. Új } \\
\text { online tanfolyamok, kreatív alkotások, DIY lakberendezés, festés, felújítás, tervezés, } \\
\text { rendrakás, nagytakarítás, szanálás a feng shui elvei szerint. Természetfotózás, napi } \\
\text { sport, egészségesebb étkezés. Pozitív énidő bevezetése. Kedvenc zenék. Amikre } \\
\text { eddig nem volt időm. A prioritások megváltoztak. " }\end{array}$ & Nő & 42 & középváros \\
\hline $\begin{array}{l}\text { „Mozgás, friss levegőn tartózkodás, pszichológiai témájú előadások, és az ott java- } \\
\text { soltak alkalmazása, egészséges ételek fogyasztása." }\end{array}$ & Nő & 38 & főváros \\
\hline
\end{tabular}

Forrás: saját szerkesztés

Intervenciós lehetőségek

A koronavírus járványhelyzet és az ehhez kapcsolódó gazdasági recesszió a globális populáció egy részének pszichés támogatását szükségessé teheti. $^{63}$

A telehealth alkalmazások a járványhelyzethez kapcsolódó karantén és izoláció során előtérbe kerültek, melyek megvalósulhatnak például videochat, e-mailek, hírlevelek, applikációk formájában. Az online-alapú egészségügyi ellátás és terápiás lehetőségek különösen ideálisak lehetnek olyan személyek számára, akik távol élnek az egészségügyi intézményektől, így a fertőzés kockázata csökkenthető náluk. A felhasználók információt kaphatnak a depresszió, szorongás vagy a PTSD tüneteiről, relaxációs módszerekről és önsegítő programokról, valamint online formában részesülhetnek krízisintervencióban, életvezetési tanácsadásban és pszichoterápiában. ${ }^{64}$ Mazza és munkatársai megemlítik cikkükben, hogy a lelkisegély-vonalaknak és az online mentálhigiénés kérdőives felmérésnek is nagy szerepe lehet a járvány pszichés terheinek csökkentésében. ${ }^{41}$

6. táblázat: „Intervenciós lehetőségek” témában a „Mik segíthetnek Önnek abban, hogy megbirkózzon a járványhelyzet okozta nehézségekkel?" kérdésre adott válaszok közül kiemelések magyar felnőttektől (n=431)

\begin{tabular}{|l|c|c|c|}
\hline \multicolumn{1}{|c|}{ Idézet } & Nem & \multicolumn{2}{c|}{ Ĺletkor } \\
\hline „Pszichológus." & Nő & 49 & nagy középváros \\
\hline „10 éves pszichoanalízis, tapasztalat, józan ész." & Férfi & 58 & fóváros \\
\hline
\end{tabular}

Forrás: saját szerkesztés

Sammons, VandenBos és Martin 3015 Egyesült Államokban gyakorló pszichológusokat kérdeztek meg arról, hogy miként érintette munkájukat a rendkívüli helyzet. ${ }^{65} \mathrm{~A}$ megkérdezett szakemberek egy-két hét alatt váltottak személyes munkamódból online segítői munkára, a telepszichológiát használók aránya közöttük 29\%-ról 80\%-ra nőtt. Az általuk öt leggyakrabban használt applikáció a következők voltak: Doxy.Me (29\%), Zoom (25\%), FaceTime (15\%), Skype (7\%), Simple Practice (4\%). ${ }^{65}$

A járványhelyzetben a pszichiátriai ellátórendszer működésének változtatása szükséges. Xiang és munkatársai kidolgoztak javaslatokat ennek megvalósítására, mint például a csoportos foglalkozások 
kerülése, vagy az újonnan felvett páciensek bejárásának korlátozása a kórház bizonyos területeire. ${ }^{66}$

Balachandar és munkatársai koronavírus-fertőzésből kigyógyult pácienseknek és családtagjaiknak fogalmaztak meg tanácsokat, mint például a következőket: érdemes megosztani érzéseiket a kezelésről, a karanténról, tünetekről a pszichológiai megterhelés csökkentése érdekében; jóga-és légzőgyakorlatok végzését; „pszicho-szakemberek” támogatásának igénybe vételét. ${ }^{67}$

Az egészségügyben dolgozó szakemberek átélhetnek fizikai és mentális fáradtságot, félelmet és bizonytalanságot a járványhelyzetben. Ornell és munkatársai javaslata szerint érdemes biztosítani pszichológiai és pszichiátriai támogatást a kórházakban és más egészségügyi intézményekben dolgozók számára. ${ }^{68}$

A Jacobson-féle progresszív izomrelaxáció csökkentheti a szorongást, és javithatja az alvásminőséget COVID-19 fertőzött pácienseknél. Kínában 51 COVID-19 pácienst random módon kísérleti és kontrollcsoportra osztottak, a kísérleti csoport tagjai 5 napon keresztül 20-30 percben progresszív izomrelaxációt végeztek, a kontrollcsoport tagjai csak a napi rutinvizsgálatokat és az orvosi ellátást kapták. Beavatkozást követően a progresszív relaxációs módszert gyakorló kísérleti csoportnál szignifikánsan csökkent a szorongás, és javult az alvásminőség a kontrollcsoporthoz képest. ${ }^{69}$

Egyes tanulmányokban a rövid kognitív viselkedésterápia, pszichológiai tanácsadás, pszichoanalitikus technikák, pszichodrámás eszközök alkalmazását is javasolják a járványhelyzetben kliensekkel végzett lelki munkában. ${ }^{25,39}$

Bizonyos pácienseknél szükség lehet pszichoterápiás és pszichofarmakológiai kombinált kezelésre. Khawam, Khouli és Pozuelo tanulmányukban bemutattak egy 62 éves, koronavírussal fertőzött nőbeteget, aki pszichoterápiás (relaxációs technikák, légzőgyakorlatok, bátorítás alkalmazásával) és pszichofarmakológiai (akut szorongásos és pániktünetek csökkentésére) kezelést kapott. ${ }^{40}$

\section{ÖSSZEGZÉS}

2020 tavaszán a magyar lakosság kénytelen volt azzal a helyzettel szembenézni, hogy a globális koronavírus-járvány Magyarországot is elérte. A fertőzés elkerülésére bevezetett, szükséges óvintézkedések a társas találkozások online formába áttevődésével, hetekig tartó otthon maradással, bizonytalanságérzettel, a vásárlási szokások megváltozásával jártak. Ez az újonnan kialakult helyzet új viselkedési formák megjelenéséhez vezethetett (például megnövekedett mennyiségú alkoholfogyasztáshoz), befolyásolta a médiahasználati szokásokat (gyakoribbá válhattak a negatív érzelmek megosztásai szociális médiafelületeken). A pszichés hatások tekintetében a distressz mértéke, a szorongásos és depressziós jegyek megnövekedése jellemző reakció volt a járványhelyzetre globálisan. Pszichológiai változók (mint például a temperamentum-típus, önbecsülés mértéke) befolyásolhatták azt, hogy miként reagál az egyén az újonnan kialakult helyzetre. Az intervenciós típusok sokféle formája jelent meg annak érdekében, hogy a járványhelyzet okozta nehézségekkel való szembenézést segítsék a szakemberek: pszichológusok munkamódja sok esetben átállt online támogatásnyújtásra; a pszichiátriai intézmények múködésmódja megváltozott; a szakemberek a gyakori lelki támogatásformákat online környezethez adaptálták. A magyar lakosság a járványhelyzetben többféle módon kérhetett lelki támogatást: a Magyar Lelki Elsősegély Telefonszolgálatok Szövetsége újabb ingyenesen hívható telefonvonalat tett elérhetővé; támogatást nyújtottak az egyházi lelkisegély-vonalak; a Pszi Pont önkéntes pszichológiai segítői a koronavírus járvány krízise kapcsán segítséget nyújtottak online vagy telefonon keresztül. $70,71,72$

Az áttekintett témakörökhöz saját vizsgálatból származó kiemeléseket illesztettünk, melyek illusztrálják a vizsgálatban résztvevő személyek szubjektív élményeit, tapasztalatait a járványhelyzethez kapcsolódó karantén és izoláció idején. Tanulmányunkban olyan javaslatokat, eredményeket foglaltunk össze, melyek segítséget nyújthatnak a 2020-as koronavírus-járvány esetlegesen fellépő magyarországi második hulláma esetén. 


\section{HIVATKOZÁSOK}

\footnotetext{
${ }^{1}$ Tájékoztató oldal a koronavírusról. Veszélyhelyzetet hirdet az ország teljes területére a kormány. 2020. Available from: https://koronavirus.gov.hu/cikkek/veszelyhelyzetet-hirdet-az-orszag-teljes-teruletere-kormany. (Elérve: 2020. 09. 03.)

${ }^{2}$ Magyarország Kormánya. Az operatív törzs veszélyhelyzet elrendelését javasolja a kormánynak. 2020. Available from: https://www.kormany.hu/hu/miniszterelnokseg/hirek/az-operativ-torzs-veszelyhelyzet-elrendeleset-javasolja-a-kormanynak. (Elérve: 2020. 09. 03.)

${ }^{3}$ Tájékoztató oldal a koronavírusról. Megelőzés. 2020. Available from: https://koronavirus.gov.hu/megelozes. (Elérve: 2020. 09. 03.)

${ }^{4}$ Tájékoztató oldal a koronavírusról. Mától kinyithatnak a fővárosi éttermek belső terei és a szálláshelyek is fogadhatnak vendégeket. 2020. Available from: https://koronavirus.gov.hu/cikkek/matol-kinyithatnak-fovarosi-ettermek-belso-tereies-szallashelyek-fogadhatnak-vendegeket. (Elérve: 2020. 09. 03.)

${ }^{5}$ Magyarország Kormánya. Péntektől látogathatók a fővárosi éttermek belső terei és a szabadtéri rendezvények. 2020. Available from: https://www.kormany.hu/hu/hirek/pentektol-latogathatok-a-fovarosi-ettermek-belso-terei-es-a-szabadteri-rendezvenyek. (Elérve: 2020. 09. 03.)

${ }^{6}$ Tájékoztató oldal a koronavírusról. Az államfő elrendelte a veszélyhelyzet megszüntetéséről szóló törvény kihirdetését. 2020. Available from: https://koronavirus.gov.hu/cikkek/az-allamfo-elrendelte-veszelyhelyzet-megszunteteserol-szolotorveny-kihirdeteset. (Elérve: 2020. 09. 03.)

${ }^{7}$ Szabo C, Kemény L. Psychological effects of the COVID-19 pandemic on the Hungarian adult population. Unpublished raw data. 2020.

${ }^{8}$ Abonyiné Palotás J, Ancsin G, Aubert A, Bánhidi M, Erdősi F, Farkas J, et al. Általános társadalomföldrajz I.-II. Budapest, Hungary: Nordex Kft. - Dialóg Campus Kiadó; 2014.

${ }^{9}$ McFadden SM, Malik AA, Aguolu OG, Willebrand KS, Omer SB. Perceptions of the adult US population regarding the novel coronavirus outbreak. PLoS One. 2020;15(4):e0231808. PubMed PMID: 32302370. Pubmed Central PMCID: PMC7164638. Epub 2020/04/18. eng.

10 Redelmeier DA, Shafir E. Pitfalls of judgment during the COVID-19 pandemic. The Lancet Public health. 2020 Jun;5(6):e306-e8. PubMed PMID: 32334647. Pubmed Central PMCID: PMC7180015. Epub 2020/04/27. eng. 11 Wang J, Wang JX, Yang GS. The Psychological Impact of COVID-19 on Chinese Individuals. Yonsei medical journal. 2020 May;61(5):438-40. PubMed PMID: 32390368. Pubmed Central PMCID: PMC7214113. Epub 2020/05/12. eng.

12 Brooks SK, Webster RK, Smith LE, Woodland L, Wessely S, Greenberg N, et al. The psychological impact of quarantine and how to reduce it: rapid review of the evidence. The Lancet. 2020;395(10227):912-20.

${ }^{13}$ Corruble E. A Viewpoint From Paris on the COVID-19 Pandemic: A Necessary Turn to Telepsychiatry. The Journal of clinical psychiatry. 2020 Mar 31;81(3). PubMed PMID: 32237302. Epub 2020/04/03. eng.

${ }^{14}$ Rahman J, Muralidharan A, Quazi SJ, Saleem H, Khan S. Neurological and Psychological Effects of Coronavirus (COVID19): An Overview of the Current Era Pandemic. Cureus. 2020 Jun 5;12(6):e8460. PubMed PMID: 32528783. Pubmed Central PMCID: PMC7282368. Epub 2020/06/13. eng.

15 Jungmann SM, Witthöft M. Health anxiety, cyberchondria, and coping in the current COVID-19 pandemic: Which factors are related to coronavirus anxiety? Journal of anxiety disorders. 2020 Jun;73:102239. PubMed PMID: 32502806. Pubmed Central PMCID: PMC7239023. Epub 2020/06/06. eng.

${ }^{16}$ Balkhi F, Nasir A, Zehra A, Riaz R. Psychological and Behavioral Response to the Coronavirus (COVID-19) Pandemic. Cureus. 2020 May 2;12(5):e7923. PubMed PMID: 32499970. Pubmed Central PMCID: PMC7265762. Epub 2020/06/06. eng.

${ }^{17}$ Balhara YPS, Kattula D, Singh S, Chukkali S, Bhargava R. Impact of lockdown following COVID-19 on the gaming behavior of college students. Indian journal of public health. 2020 Jun;64(Supplement):S172-S6. PubMed PMID: 32496250. Epub 2020/06/05. eng.

${ }^{18}$ Song W, Jin X, Gao J, Zhao T. Will Buying Follow Others Ease Their Threat of Death? An Analysis of Consumer Data during the Period of COVID-19 in China. Int J Environ Res Public Health. 2020 May 6;17(9). PubMed PMID: 32384598. Pubmed Central PMCID: PMC7246543. Epub 2020/05/10. eng.

${ }^{19}$ Mazza C, Ricci E, Biondi S, Colasanti M, Ferracuti S, Napoli C, et al. A Nationwide Survey of Psychological Distress among Italian People during the COVID-19 Pandemic: Immediate Psychological Responses and Associated Factors. Int J Environ Res Public Health. 2020 May 2;17(9). PubMed PMID: 32370116. Pubmed Central PMCID: PMC7246819. Epub 2020/05/07. eng.

${ }^{20}$ Wagner KD. Addressing the Experience of Children and Adolescents During the COVID-19 Pandemic. The Journal of clinical psychiatry. 2020 Apr 21;81(3). PubMed PMID: 32316079. Epub 2020/04/22. eng.
} 
${ }^{21}$ Seidi PAM, Ardebil MD, Jaff D. COVID-19 pandemic: New challenge to securing mental well-being in conflict settings. Asian J Psychiatr. 2020 May 5;51:102151. PubMed PMID: 32408247. Pubmed Central PMCID: PMC7198392 competing financial interests or personal relationships that could have appeared to influence the work reported in this correspondence. Epub 2020/05/15. eng.

${ }^{22}$ Mesa Vieira C, Franco OH, Gómez Restrepo C, Abel T. COVID-19: The forgotten priorities of the pandemic. Maturitas. 2020 Jun;136:38-41. PubMed PMID: 32386664. Pubmed Central PMCID: PMC7195319. Epub 2020/05/11. eng.

${ }^{23}$ Altena E, Baglioni C, Espie CA, Ellis J, Gavriloff D, Holzinger B, et al. Dealing with sleep problems during home confinement due to the COVID-19 outbreak: Practical recommendations from a task force of the European CBT-I Academy. Journal of sleep research. 2020 Apr 4:e13052. PubMed PMID: 32246787. Epub 2020/04/05. eng.

${ }^{24}$ Wang C, Pan R, Wan X, Tan Y, Xu L, Ho CS, et al. Immediate Psychological Responses and Associated Factors during the Initial Stage of the 2019 Coronavirus Disease (COVID-19) Epidemic among the General Population in China. Int J Environ Res Public Health. 2020 Mar 6;17(5). PubMed PMID: 32155789. Pubmed Central PMCID: PMC7084952. Epub 2020/03/12. eng.

${ }^{25}$ Khan S, Siddique R, Li H, Ali A, Shereen MA, Bashir N, et al. Impact of coronavirus outbreak on psychological health. Journal of global health. 2020 Jun;10(1):010331. PubMed PMID: 32355556. Pubmed Central PMCID: PMC7180007 form (available upon request from the corresponding author) and declare no conflicts of interest. Epub 2020/05/02. eng. ${ }^{26}$ Ćosić K, Popović S, Šarlija M, Kesedžić I. Impact of Human Disasters and COVID-19 Pandemic on Mental Health: Potential of Digital Psychiatry. Psychiatr Danub. 2020 Spring;32(1):25-31. PubMed PMID: 32303026. Epub 2020/04/18. eng.

${ }^{27}$ Zhang Y, Ma ZF. Impact of the COVID-19 Pandemic on Mental Health and Quality of Life among Local Residents in Liaoning Province, China: A Cross-Sectional Study. Int J Environ Res Public Health. 2020 Mar 31;17(7). PubMed PMID: 32244498. Pubmed Central PMCID: PMC7177660. Epub 2020/04/05. eng.

${ }^{28}$ Ren Y, Zhou Y, Qian W, Li Z, Liu Z, Wang R, et al. Letter to the Editor "A longitudinal study on the mental health of general population during the COVID-19 epidemic in China". Brain, behavior, and immunity. 2020 Jul;87:132-3. PubMed PMID: 32387510. Pubmed Central PMCID: PMC7201232. Epub 2020/05/11. eng.

${ }^{29}$ Cullen W, Gulati G, Kelly BD. Mental health in the COVID-19 pandemic. QJM: monthly journal of the Association of Physicians. 2020 May 1;113(5):311-2. PubMed PMID: 32227218. Pubmed Central PMCID: PMC7184387. Epub 2020/04/01. eng.

${ }^{30}$ Holmes EA, O'Connor RC, Perry VH, Tracey I, Wessely S, Arseneault L, et al. Multidisciplinary research priorities for the COVID-19 pandemic: a call for action for mental health science. The lancet Psychiatry. 2020 Jun;7(6):547-60. PubMed PMID: 32304649. Pubmed Central PMCID: PMC7159850. Epub 2020/04/19. eng.

${ }^{31}$ Liu S, Yang L, Zhang C, Xiang YT, Liu Z, Hu S, et al. Online mental health services in China during the COVID-19 outbreak. The lancet Psychiatry. 2020 Apr;7(4):e17-e8. PubMed PMID: 32085841. Pubmed Central PMCID: PMC7129099. Epub 2020/02/23. eng.

${ }^{32}$ Ansari M, Ahmadi Yousefabad S. Potential threats of COVID-19 on quarantined families. Public health. 2020 Jun;183:1. PubMed PMID: 32380343. Pubmed Central PMCID: PMC7172715. Epub 2020/05/08. eng.

${ }^{33}$ Li W, Yang Y, Liu ZH, Zhao YJ, Zhang Q, Zhang L, et al. Progression of Mental Health Services during the COVID-19 Outbreak in China. International journal of biological sciences. 2020;16(10):1732-8. PubMed PMID: 32226291. Pubmed Central PMCID: PMC7098037. Epub 2020/04/01. eng.

${ }^{34}$ Shigemura J, Ursano RJ, Morganstein JC, Kurosawa M, Benedek DM. Public responses to the novel 2019 coronavirus (2019-nCoV) in Japan: Mental health consequences and target populations. Psychiatry and clinical neurosciences. 2020 Apr;74(4):281-2. PubMed PMID: 32034840. Pubmed Central PMCID: PMC7168047. Epub 2020/02/09. eng.

${ }^{35}$ Steenblock C, Todorov V, Kanczkowski W, Eisenhofer G, Schedl A, Wong ML, et al. Severe acute respiratory syndrome coronavirus 2 (SARS-CoV-2) and the neuroendocrine stress axis. Molecular psychiatry. 2020 May 7:1-7. PubMed PMID: 32382135. Pubmed Central PMCID: PMC7204611. Epub 2020/05/10. eng.

${ }^{36}$ Ozamiz-Etxebarria N, Dosil-Santamaria M, Picaza-Gorrochategui M, Idoiaga-Mondragon N. Stress, anxiety, and depression levels in the initial stage of the COVID-19 outbreak in a population sample in the northern Spain. Cadernos de saude publica. 2020;36(4):e00054020. PubMed PMID: 32374806. Epub 2020/05/07. Niveles de estrés, ansiedad y depresión en la primera fase del brote del COVID-19 en una muestra recogida en el norte de España. eng ${ }^{37}$ Fiorillo A, Gorwood P. The consequences of the COVID-19 pandemic on mental health and implications for clinical practice. European psychiatry: the journal of the Association of European Psychiatrists. 2020 Apr 1;63(1):e32. PubMed PMID: 32234102. Pubmed Central PMCID: PMC7156565. Epub 2020/04/03. eng.

${ }^{38}$ Wind TR, Rijkeboer M, Andersson G, Riper H. The COVID-19 pandemic: The 'black swan' for mental health care and a turning point for e-health. Internet interventions. 2020 Apr;20:100317. PubMed PMID: 32289019. Pubmed Central PMCID: PMC7104190. Epub 2020/04/15. eng. 
${ }^{39}$ Marčinko D, Jakovljević M, Jakšić N, Bjedov S, Mindoljević Drakulić A. The Importance of Psychodynamic Approach during COVID-19 Pandemic. Psychiatr Danub. 2020 Spring;32(1):15-21. PubMed PMID: 32303024. Epub 2020/04/18. eng.

${ }^{40}$ Khawam E, Khouli H, Pozuelo L. Treating acute anxiety in patients with COVID-19. Cleveland Clinic journal of medicine. 2020 May 14. PubMed PMID: 32409438. Epub 2020/05/16. eng.

${ }^{41}$ Mazza M, Marano G, Antonazzo B, Cavarretta E, Di Nicola M, Janiri L, et al. What about heart and mind in the covid19 era? Minerva cardioangiologica. 2020 May 12. PubMed PMID: 32397693. Epub 2020/05/14. eng.

42 Zhao X, Lan M, Li H, Yang J. Perceived stress and sleep quality among the non-diseased general public in China during the 2019 coronavirus disease: a moderated mediation model. Sleep medicine. 2020 May 21. PubMed PMID: 32482485. Pubmed Central PMCID: PMC7240276. Epub 2020/06/03. eng.

${ }^{43}$ van Agteren J, Bartholomaeus J, Fassnacht DB, lasiello M, Ali K, Lo L, et al. Using Internet-Based Psychological Measurement to Capture the Deteriorating Community Mental Health Profile During COVID-19: Observational Study. JMIR mental health. 2020 Jun 11;7(6):e20696. PubMed PMID: 32490845. Pubmed Central PMCID: PMC7294997. Epub 2020/06/04. eng.

${ }^{44}$ Mackolil J, Mackolil J. Addressing psychosocial problems associated with the COVID-19 lockdown. Asian J Psychiatr. 2020 May 8;51:102156. PubMed PMID: 32413617. Pubmed Central PMCID: PMC7207101. Epub 2020/05/16. eng.

${ }^{45}$ Lei L, Huang X, Zhang S, Yang J, Yang L, Xu M. Comparison of Prevalence and Associated Factors of Anxiety and Depression Among People Affected by versus People Unaffected by Quarantine During the COVID-19 Epidemic in Southwestern China. Medical science monitor: international medical journal of experimental and clinical research. 2020 Apr 26;26:e924609. PubMed PMID: 32335579. Pubmed Central PMCID: PMC7199435. Epub 2020/04/27. eng.

${ }^{46}$ Shuja KH, Aqeel M, Jaffar A, Ahmed A. COVID-19 Pandemic and Impending Global Mental Health Implications. Psychiatr Danub. 2020 Spring;32(1):32-5. PubMed PMID: 32303027. Epub 2020/04/18. eng.

${ }^{47}$ Ahmed MZ, Ahmed O, Aibao Z, Hanbin S, Siyu L, Ahmad A. Epidemic of COVID-19 in China and associated Psychological Problems. Asian J Psychiatr. 2020 Apr 14;51:102092. PubMed PMID: 32315963. Pubmed Central PMCID:

PMC7194662. Epub 2020/04/22. eng.

${ }^{48}$ Asmundson GJG, Taylor S. How health anxiety influences responses to viral outbreaks like COVID-19: What all decision-makers, health authorities, and health care professionals need to know. Journal of anxiety disorders. 2020 Apr;71:102211. PubMed PMID: 32179380. Pubmed Central PMCID: PMC7271220. Epub 2020/03/18. eng.

${ }^{49}$ González-Sanguino C, Ausín B, Castellanos M, Saiz J, López-Gómez A, Ugidos C, et al. Mental health consequences during the initial stage of the 2020 Coronavirus pandemic (COVID-19) in Spain. Brain, behavior, and immunity. 2020 Jul;87:172-6. PubMed PMID: 32405150. Pubmed Central PMCID: PMC7219372. Epub 2020/05/15. eng.

${ }^{50}$ Lima CKT, Carvalho PMM, Lima I, Nunes J, Saraiva JS, de Souza RI, et al. The emotional impact of Coronavirus 2019nCoV (new Coronavirus disease). Psychiatry research. 2020 May;287:112915. PubMed PMID: 32199182. Pubmed Central PMCID: PMC7195292. Epub 2020/03/22. eng.

${ }^{51}$ Moccia L, Janiri D, Pepe M, Dattoli L, Molinaro M, De Martin V, et al. Affective temperament, attachment style, and the psychological impact of the COVID-19 outbreak: an early report on the Italian general population. Brain, behavior, and immunity. 2020 Jul;87:75-9. PubMed PMID: 32325098. Pubmed Central PMCID: PMC7169930. Epub 2020/04/24. eng.

52 Bhatia MS, Goyal S, Singh A, Daral A. COVID-19 Pandemic-Induced Panic Disorder. The primary care companion for CNS disorders. 2020 Apr 30;22(3). PubMed PMID: 32369687. Epub 2020/05/06. eng.

${ }^{53}$ Fischer M, Coogan AN, Faltraco F, Thome J. COVID-19 paranoia in a patient suffering from schizophrenic psychosis - a case report. Psychiatry research. 2020 Jun;288:113001. PubMed PMID: 32315884. Pubmed Central PMCID:

PMC7162758 interests. Epub 2020/04/22. eng.

${ }^{54}$ Hajdúk M, Dančík D, Januška J, Svetský V, Straková A, Turček M, et al. Psychotic experiences in student population during the COVID-19 pandemic. Schizophrenia research. 2020 May 13. PubMed PMID: 32405153. Pubmed Central PMCID: PMC7218396. Epub 2020/05/15. eng.

${ }^{55}$ Xue Z, Lin L, Zhang S, Gong J, Liu J, Lu J. Sleep problems and medical isolation during the SARS-CoV-2 outbreak. Sleep medicine. 2020 Jun;70:112-5. PubMed PMID: 32361216. Pubmed Central PMCID: PMC7172848 Potential Conflicts of Interest associated with this article can be viewed by clicking on the following link:

https://doi.org/10.1016/j.sleep.2020.04.014. Epub 2020/05/04. eng.

${ }^{56}$ Taylor S, Landry CA, Paluszek MM, Fergus TA, McKay D, Asmundson GJG. Development and initial validation of the COVID Stress Scales. Journal of anxiety disorders. 2020 May;72:102232. PubMed PMID: 32408047. Pubmed Central PMCID: PMC7198206. Epub 2020/05/15. eng. 
${ }^{57}$ Lee SA. How much "Thinking" about COVID-19 is clinically dysfunctional? Brain, behavior, and immunity. 2020 Jul;87:97-8. PubMed PMID: 32353520. Pubmed Central PMCID: PMC7185010. Epub 2020/05/01. eng.

${ }^{58}$ Colizzi M, Bortoletto R, Silvestri M, Mondini F, Puttini E, Cainelli C, et al. Medically unexplained symptoms in the times of Covid-19 pandemic: a case-report. Brain, behavior, \& immunity - health. 2020 Apr 19;5:100073. PubMed PMID: 32313886. Pubmed Central PMCID: PMC7166302. Epub 2020/04/22. eng.

59 Li S, Wang Y, Xue J, Zhao N, Zhu T. The Impact of COVID-19 Epidemic Declaration on Psychological Consequences: A Study on Active Weibo Users. Int J Environ Res Public Health. 2020 Mar 19;17(6). PubMed PMID: 32204411. Pubmed Central PMCID: PMC7143846. Epub 2020/03/25. eng.

${ }^{60}$ Lwin MO, Lu J, Sheldenkar A, Schulz PJ, Shin W, Gupta R, et al. Global Sentiments Surrounding the COVID-19 Pandemic on Twitter: Analysis of Twitter Trends. JMIR public health and surveillance. 2020 May 22;6(2):e19447. PubMed PMID: 32412418. Pubmed Central PMCID: PMC7247466. Epub 2020/05/16. eng.

${ }^{61}$ Chao M, Xue D, Liu T, Yang H, Hall BJ. Media use and acute psychological outcomes during COVID-19 outbreak in China. Journal of anxiety disorders. 2020 2020/08/01/;74:102248.

${ }^{62}$ Shen X, Zou X, Zhong X, Yan J, Li L. Psychological stress of ICU nurses in the time of COVID-19. Critical care (London, England). 2020 May 6;24(1):200. PubMed PMID: 32375848. Pubmed Central PMCID: PMC7202793. Epub 2020/05/08. eng.

${ }^{63}$ Mindoljević Drakulić A, Radman V. Crisis Psychodrama in the Era of COVID-19. Psychiatr Danub. 2020 Spring;32(1):22-

4. PubMed PMID: 32303025. Epub 2020/04/18. eng.

${ }^{64}$ Zhou X, Snoswell CL, Harding LE, Bambling M, Edirippulige S, Bai X, et al. The Role of Telehealth in Reducing the Mental Health Burden from COVID-19. Telemedicine journal and e-health : the official journal of the American Telemedicine Association. 2020 Apr;26(4):377-9. PubMed PMID: 32202977. Epub 2020/03/24. eng.

${ }^{65}$ Sammons MT, VandenBos GR, Martin JN. Psychological Practice and the COVID-19 Crisis: A Rapid Response Survey. Journal of health service psychology. 2020 May 8:1-7. PubMed PMID: 32395720. Pubmed Central PMCID: PMC7209971. Epub 2020/05/13. eng.

${ }^{66}$ Xiang YT, Zhao YJ, Liu ZH, Li XH, Zhao N, Cheung T, et al. The COVID-19 outbreak and psychiatric hospitals in China: managing challenges through mental health service reform. International journal of biological sciences. 2020;16(10):1741-4. PubMed PMID: 32226293. Pubmed Central PMCID: PMC7098035. Epub 2020/04/01. eng. ${ }^{67}$ Balachandar V, Mahalaxmi I, Subramaniam M, Kaavya J, Senthil Kumar N, Laldinmawii G, et al. Follow-up studies in COVID-19 recovered patients - is it mandatory? The Science of the total environment. 2020 Aug 10;729:139021. PubMed PMID: 32360909. Pubmed Central PMCID: PMC7184970. Epub 2020/05/04. eng.

${ }^{68}$ Ornell F, Halpern SC, Kessler FHP, Narvaez JCdM. The impact of the COVID-19 pandemic on the mental health of healthcare professionals. Cadernos de saude publica. 2020;36.

${ }^{69}$ Liu K, Chen Y, Wu D, Lin R, Wang Z, Pan L. Effects of progressive muscle relaxation on anxiety and sleep quality in patients with COVID-19. Complementary therapies in clinical practice. 2020 May;39:101132. PubMed PMID: 32379667. Pubmed Central PMCID: PMC7102525. Epub 2020/05/08. eng.spa.

${ }^{70} \mathrm{MTI} / \mathrm{WEBBeteg}$. Koronavírus - Újabb telefonvonalon érhető el a lelkielsősegély-szolgálat. 2020. Available from: https://www.webbeteg.hu/cikkek/egeszsegugy/25001/koronavirus-es-lelkisegely-telefonszam. (Elérve: 2020. 09. 03.)

${ }^{71}$ Tájékoztató oldal a koronavírusról. Egyházi lelkisegély-vonalak: segítség a járványban is. 2020. Available from: https://koronavirus.gov.hu/cikkek/egyhazi-lelkisegely-vonalak-segitseg-jarvanyban. (Elérve: 2020. 09. 03.)

72 PsziPont-Probono. Önkéntes pszichológiai segítők a koronavírus COVID-19 járvány kapcsán. 2020. Available from: https://pszi.hu/. (Elérve: 2020. 09. 03.) 